\title{
Phytochemical study and anti-inflammatory effect of Psychotria stenocalyx (Rubiaceae)
}

\author{
Gustavo Silva Queiroz ${ }^{1}$, Ana Beatriz Gobbo Luz ${ }^{2}$, Marcus Vinícius Pereira dos Santos Nascimento ${ }^{2}$, Sergio Scherrer \\ Thomasi $^{3}$, Antonio Gilberto Ferreira ${ }^{4}$, Eduardo Monguilhott Dalmarco ${ }^{2}$, Ines Maria Costa Brighente ${ }^{1 *}$ \\ ${ }^{1}$ Department of Chemistry,Federal University of Santa Catarina, Florianópolis - SC, Brazil. \\ ${ }^{2}$ Department of Clinical Analysis, Federal University of Santa Catarina, Florianópolis - SC, Brazil. \\ ${ }^{3}$ Department of Chemistry, Federal University of Lavras, Lavras - MG, Brazil. \\ ${ }^{4}$ Department of Chemistry, Federal University of São Carlos, São Carlos - SP, Brazil.
}

\section{ARTICLE INFO}

Article history:

Received on: 31/01/2017

Accepted on: 23/03/2017

Available online: 30/04/2017

Key words:

Psychotria stenocalyx, antiinflammatory, monoterpene indole alkaloids, HPLCDAD-SPE/NMR.

\begin{abstract}
In this study, an in vivo anti-inflammatory assay was conducted on Psychotria stenocalyx ethanol extract of leaves, evaluating this effect on cell migration and exudate formation in a murine carrageenan-induced model of pleurisy. The extract showed the optimum dose, at $400 \mathrm{mg} / \mathrm{kg}$, inhibiting cellular and vascular parameters: total leucocytes due to polymorphonuclear migration and exudate formation $(\mathrm{p}<0.01)$. A phytochemical study was conducted using the hyphenated techniques HPLC-DAD-SPE/NMR and HPLC-DAD-ESI-TOF-HRMS, in which seven monoterpene indole alkaloids were identified: lyaloside 1, (E)-O-(6')-cinnamoyl-4"-hydroxy-3",5"dimethoxy-lyaloside $\mathbf{2}$, strictosamide 3 , pauridianthoside $\mathbf{4}$, vallesiachotamine lactone $\mathbf{5}$, E-vallesiachotamine $\mathbf{6}$ and Z-vallesiachotamine 7, in the alkaloid fraction, obtained by an acid-base extraction on P. stenocalyx crude extract. This is the first study developed with this species.
\end{abstract}

\section{INTRODUCTION}

Psychotria L. is the largest genus in the tribe Psychotrieae (Rubiaceae) and is comprised of around 2000 species worldwide, distributed in tropical regions (Nepokroeff $e t$ al., 1999).

Many biological and pharmacological investigations of the genus Psychotria have shown a significant number of activities, such as antioxidant (Formagio et al., 2014), antibacterial (Moraes et al., 2011), anti-parasitic (Kato et al., 2012), antitumor (Gerlach et al., 2010), anti-inflammatory (Iniyavan et al., 2012), anxiolytic and anti-depressive (Farias et al., 2012), and anti-epileptic (Awad et al., 2009) activities. Studies have also reported the efficacy of $P$. poeppigiana against heart disease, cough, asthma and bronchitis (Guerrero et al., 2010). Species of Psychotriawas also evaluated for their ability

* Corresponding Author

Email: ines.maria@ufsc.br to protect against intracellular amyloid toxicity and induced cell differentiation (Currais et al., 2014). Chemical studies on Psychotria species have reported the presence of alkaloids as the main secondary metabolites, particularly monoterpene indole alkaloids (Calixto et al., 2016). Themonoterpene indole alkaloids lyaloside 1, (E)-O-(6')-cinnamoyl-4"-hydroxy-3",5"-dimethoxylyaloside $\mathbf{2}$, strictosamide $\mathbf{3}$, pauridianthoside $\mathbf{4}$, vallesiachotamine lactone 5, E-vallesiachotamine 6, and Z-vallesiachotamine 7have previously been reported in Psychotria species (Berger et al., 2015; Farias et al., 2009; Passos, et al., 2013a-b; Paul et al., 2003). The genus Psychotria can also be characterized as an abundant source of indoles (Gerlach et al., 2010), pyrrolidinoindole (Henriques et al., 2004), quinolin and isoquinolin (Bernhard et al., 2011), and $\beta$-carboline (Murillo and Castro, 1998) alkaloids. Some of these alkaloids inhibited monoamine oxidase $\mathrm{A}$ and $\mathrm{B}$ (Passos et al., 2013a), and exhibited potential inhibition of the enzymes acetylcholinesterase and butyrylcholinesterase (Passos et al., 2013b). 
Psychotria stenocalyx Müll. Arg. is a shrub that grows up to two meters, and occurs in coastal tropical forests of South and Southeast Brazil, ranging from Rio de Janeiro to Santa Catarina (Taylor et al., 2015). It is popularly known as "gandiúva-d'anta" and "café-d'anta" (Dillenburg et al., 1985).

In view of the many reports that cite the important biological activity of Psychotria, the aim of this study was to carry out an in vivo anti-inflammatory assay on the leaf extract, and to isolate and structurally elucidate monoterpene indole alkaloids on Psychotria stenocalyx.

\section{MATERIAL AND METHODS}

\section{Plant Material}

The aerial parts of Psychotria stenocalyx were collected in June 2012 in Florianópolis, state of Santa Catarina, Brazil. The plant was identified by botanist Ademir Reis and a voucher was deposited in the "Barbosa Rodrigues" Herbarium in Itajaí, state of Santa Catarina, Brazil, under number HBR55428.

\section{Extraction of plant material}

Air-dried and powdered leaves of $P$. stenocalyx (449 g) were extracted with ethanol $96 \%(3 \times 72 \mathrm{~h})$ at room temperature. After filtration, the extract was concentrated to obtain the crude extract, CE (5.54 g/100g dried leaves) for use in the inflammation study. The CE was dissolved in $0.01 \mathrm{~mol} / \mathrm{L} \mathrm{HCl} \mathrm{H}{ }_{2} \mathrm{O} / \mathrm{EtOH}$ (80:20 $\mathrm{v} / \mathrm{v}$ ) and then stored in a refrigerator. After $24 \mathrm{~h}$, the extract was filtered and exhaustively extracted with ethyl acetate to remove the nonpolar constituents. The acid extract was alkalinized with $10 \%$ $\mathrm{NH}_{4} \mathrm{OH}$ in water up to $\mathrm{pH} 11$ and extracted again with ethyl acetate yielding the purified alkaloid fraction (3.24 g/100g CE) which was used for the isolation and characterization of alkaloids.

\section{Inflammation study}

Animals

In the present protocol, one month old female Swiss mice weighing 20 to $25 \mathrm{~g}$ were housed under standardized conditions ( $20 \pm 2{ }^{\circ} \mathrm{C}, 12 \mathrm{~h}$ light/dark cycles) with free access to chow and water. The experiments were designed to minimize the animal suffering and the $3 \mathrm{R}$ recommendations were followed (replacement, reduction and refinement) (Flecknell 2002). The experiments were carried out on the ethanolic crude extract of $P$. stenocalyx according to the regulations of the Brazilian College of Animal Experimentation (COBEA) and are in accordance with the rules of the Committee for Ethics in Animal Research of the Federal University of Santa Catarina (CEUA - PP00965).

\section{Experimental design of the murine model of pleurisy}

The pleurisy induction was performed as previously reported (Saleh et al., 1996). Briefly, on the day of the experiments the animals were randomly divided into different groups ( $n=6$ animals/group) and challenged with Evans Blue dye solution $(25 \mathrm{mg} / \mathrm{kg}$ ) administered intravenously (i.v). Next, the groups received the appropriate treatment as follows: (a) blank control (S), animals pre-treated with intraperitoneal (i.p.) saline (vehicle) $0.5 \mathrm{~h}$ before pleurisy induction with saline; (b) negative control $(\mathrm{Cg})$, animals treated with i.p. saline (vehicle) $0.5 \mathrm{~h}$ before pleurisy induction with carrageenan; (c) positive control (Dex), animals pre-treated with i.p. dexamethasone $0.5 \mathrm{mg} / \mathrm{kg}$ before pleurisy induction with carrageenan; and (d) experimental groups, animals pre-treated with i.p. Psychotria stenocalyx crude extract at doses ranging from 100 to $400 \mathrm{mg} / \mathrm{kg}$ before pleurisy induction with carrageenan.

After $0.5 \mathrm{~h}$ of intraperitneal (i.pl) treatment with saline, each group received a single injection of a $\lambda$-carrageenan solution $(0.1 \mathrm{~mL}, 1 \%)$ from the right side of the thoracic cavity, to induce pleurisy induction, except for the blank control group (S), which received an i.pl. sterile saline injection $(0.1 \mathrm{~mL})$. Four hours after pleurisy induction, the animals were euthanized using an overdose of xylazine and ketamine $(50 \mathrm{mg} / \mathrm{kg}$ and $250 \mathrm{mg} / \mathrm{kg}$, i.p. $)$, and the pleural cavity was exposed and washed with $1.0 \mathrm{~mL}$ of sterile phosphate buffered saline (PBS, pH 7.2) (Laborclin, Pinhais, Paraná, Brazil) containing heparin $(20 \mathrm{IU} / \mathrm{mL})$. The pleural fluid was used to measure the inflammatory parameters: total and differential leukocyte count and exudate concentration.

\section{Quantification of the leukocyte content and exudation}

To quantify the leukocyte content, pleural fluid samples were submitted to a veterinarian automatic counter (BC-2800 Vet, Mindray, Nanshan, Shenzhen, China). For the differential leukocyte count, cytospin preparations from the exudates were stained with May-Grünwald-Giemsa. The results were expressed as the total number of cells $\left(\times 10^{6}\right.$ cells $\left./ \mathrm{mL}\right)$.

The exudate quantification was performed indirectly by measuring the amount of Evans blud dye in the pleural cavity. The fluid samples were centrifuged ( $300 \mathrm{~g}$ for $5 \mathrm{~min}$ ) (SorvallTMST40, ThermoScientific $\AA$, Swedesboro, New Jersey, USA) and $200 \mu \mathrm{L}$ of the supernatant was transferred to a 96 well-ELISA plate. The amount of dye was estimated by a colorimetric measurement at $620 \mathrm{~nm}$, using an ELISA plate reader (OrganonTeknika, Roseland, New Jersey, USA). The results were expressed in $\mu \mathrm{g} / \mathrm{mL}$ by interpolation from an Evans blue dye standard curve ranging from 0.01 to $50 \mu \mathrm{g} / \mathrm{mL}$.

\section{Statistical analysis}

All data were expressed as mean \pm SEM. Statistical differences between groups were tested by one-way analysis of variance (ANOVA) followed by Dunnett's post-hoc test. The results were analyzed using GraphPad Prism v5.0 software (GraphPad Software Inc., San Diego, California, USA) and values of $\mathrm{P}<0.05$ were considered significant.

\section{HPLC analyses and isolation of compounds}

The alkaloid fraction of $P$. stenocalyx crude extract (50 $\mathrm{mg}$ ) was dissolved in $1 \mathrm{~mL} \mathrm{MeOH}$. The solution was filtered through a PVDF membrane syringe filter $(25 \mathrm{~mm}, 0.45 \mu \mathrm{m}$; Tedia Brazil) before HPLC analysis. A reversed-phase Luna C18 (Phenomenex, $150 \times 4.6 \mathrm{~mm}, 3 \mu \mathrm{m}, 100 \AA$ ) was used for the 
chromatographic separation. Gradient elution was performed using a combination eluent (A) consisting of $\mathrm{H}_{2} \mathrm{O} / \mathrm{MeCN}(95: 5$, v/v), and organic eluent (B) consisting of $\mathrm{H}_{2} \mathrm{O} / \mathrm{MeCN}(5: 95, \mathrm{v} / \mathrm{v})$, both acidified with $0.1 \%$ formic acid (Tedia Brazil). The gradient method was: 0 min, $15 \% \mathrm{~B}$; $60 \mathrm{~min}, 65 \% \mathrm{~B}$; $65-75 \mathrm{~min}, 100 \% \mathrm{~B}$; $76-85 \mathrm{~min}, 15 \% \mathrm{~B}$. Elution rate $0.5 \mathrm{~mL} / \mathrm{min}$. The injection volume was $10 \mu \mathrm{L}$ and UV traces were monitored at 254, 280, and 330 nm. HPLC-DAD-SPE/NMR analysis was carried out on an Agilent 1200 HPLC. Compounds 3-7 were adsorbed on solidphase extraction cartridges (HySphere Resin GP, $10 \mathrm{~mm} \times 2 \mathrm{~mm}$, $10 \mu \mathrm{m}$ spherical polydivinylbenzene stationary phase) using an automatic cartridge exchanger (Bruker Biospin $\mathrm{GmbH}$ ). Twenty consecutive chromatographic runs were performed, with $10 \mu \mathrm{L}$ injections and a flow rate of $1.0 \mathrm{~mL} / \mathrm{min}$. After the adsorption process, the cartridges were dried with nitrogen for $30 \mathrm{~min}$ to remove residual solvent. Deuterated $\mathrm{MeOH}-\mathrm{d} 4$ (99.8\% D) was used to elute the compounds from the SPE cartridges directly into NMR tubes (Bruker, $3 \mathrm{~mm}$ o.d.). NMR experiments were performed with a Bruker Avance III system $\left({ }^{1} \mathrm{H}\right.$ operating frequency of $600.13 \mathrm{MHz}$ ) equipped with a Bruker SampleJet sample changer and a cryogenically cooled gradient inverse tripleresonance $5.0 \mathrm{~mm}$ TCI probe-head (Bruker Biospin) optimized for ${ }^{1} \mathrm{H}$ and ${ }^{13} \mathrm{C}$ observation. Icon NMR (ver. 4.2, Bruker Biospin) was used to control the automated acquisition of NMR data, which were then processed using Topspin (version 3.0, Bruker Biospin). The HRMS and UV spectra were obtained in positive mode in a HPLC-DAD-ESI-TOF-MS instrument consisting of a Shimadzu Prominence LC-20AD UFLC system (Kyoto, Japan), using a Tpiece splitter to direct $1 \%$ of the HPLC eluate to a micrOTOF-Q II mass spectrometer (Bruker Daltonik, Bremen, Germany) equipped with an electrospray ionization interface. Mass spectra were acquired in positive-ion mode, using a drying temperature of $200{ }^{\circ} \mathrm{C}$, capillary voltage of $4500 \mathrm{~V}$, nebulizer pressure of $3.0 \mathrm{bar}$, and drying gas flow of $12 \mathrm{~L} / \mathrm{min}$.

\section{RESULTS AND DISCUSSION}

\section{Anti-inflammatory effect}

The inflammatory model adopted in the present work uses carrageenan as the phlogistic agent, to trigger an inflammatory reaction in the pleural cavity and the consequent damage associated with this process. In this specific model, it is possible to evaluate the cell migration, mainly polymorphonuclear, and exudate formation that is present in several acute inflammatory conditions (Luz et al., 2016; Saleh et al., 1996; Schmid-Schönbein, 2006).

It was reported that the alkaloid extract of Psychotria myriantha was able to inhibit in vitro polymorphonuclear leukocyte chemotaxis, and that this activity was attributed to its alkaloids myrianthosine and strictosidinic acid (Simões-Pires et al., 2006). A decrease in carrageenan-induced inflammation was also reported for the crude extract of Psychotria nilgiriensis fruits (Iniyavan et al., 2012). Regarding cell migration, P. stenocalyx extract significantly reduced total leukocyte migration to the pleural cavity of animals challenged with a $1 \%$ carrageenan solution at all the tested doses (\% inhibition: $400 \mathrm{mg} / \mathrm{kg}: 53.6 \pm$ 5.6; $200 \mathrm{mg} / \mathrm{kg}: 57.1 \pm 5.2$ and $100 \mathrm{mg} / \mathrm{kg}: 31.4 \pm 6.8)(\mathrm{p}<0.001)$ (Figure 1a). This inhibition was due to polymorphonuclear inhibition (\% inhibition: $400 \mathrm{mg} / \mathrm{kg}: 56.1 \pm 5.1 ; 200 \mathrm{mg} / \mathrm{kg}: 57.3 \pm$ 5.1 and $100 \mathrm{mg} / \mathrm{kg}$ : $32.0 \pm 6.7)(\mathrm{p}<0.01)$ (Figure 1b). As expected, the positive control group that was pre-treated with dexamethasone $0.5 \mathrm{mg} / \mathrm{kg}$ also reduced leukocyte migration (\% inhibition: $62.1 \pm 2.7)(\mathrm{p}<0.001)$ (Figure 1), due to the decrease in polymorphonuclear migration $(\%$ inhibition: $63.4 \pm 2.7)(\mathrm{p}<$ 0.001) (Figure 1b).
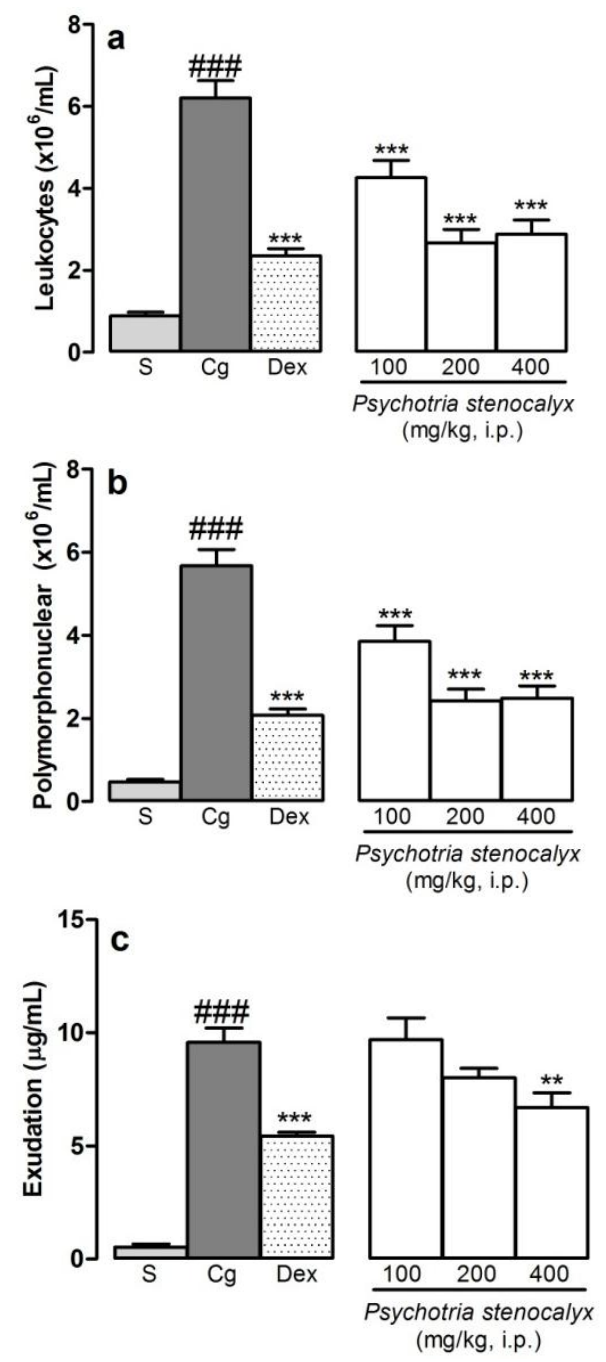

Fig. 1: Psychotria stenocalyx leaf extract (100-400 $\mathrm{mg} / \mathrm{kg})$ effect on (a) leukocyte migration, (b) polymorphonuclear migration, and (c) exudate concentration when administered intraperitoneally $0.5 \mathrm{~h}$ prior to carrageenan induced pleurisy in mice. S: blank control group, animals pre-treated with intraperitoneal (i.p.) saline $0.5 \mathrm{~h}$ before pleurisy induction with saline; $\mathrm{Cg}$ : negative control, animals treated with i.p. saline $0.5 \mathrm{~h}$ before pleurisy induction with carrageenan; Dex: positive control, animals pre-treated with i.p. dexamethasone $0.5 \mathrm{mg} / \mathrm{kg}$ before pleurisy induction with carrageenan; Psychotria stenocalyx: experimental groups, animals pre-treated with i.p. Psychotria stenocalyx extract at doses ranging from 100 to $400 \mathrm{mg} / \mathrm{kg}$ before pleurisy induction with carrageenan. The results are expressed as mean $\pm S E M$. $\mathrm{N}=6$ animals/group. $* * \mathrm{p}<0.01$ compared to $\mathrm{Cg}$ group, $* * * \mathrm{p}<0.001$ compared to $\mathrm{Cg}$ group, \#\#\# $\mathrm{p}<0.001$ compared to $\mathrm{S}$ group. 
Exudate formation was significantly inhibited by $P$. stenocalyx extract only at the $400 \mathrm{mg} / \mathrm{kg}$ dose (\% inhibition: 30.1 $\pm 6.7)(\mathrm{p}<0.01)($ Figure 1c). This result corroborates Moraes et al. 2011, who showed that the species $P$. suterella $P$. stachyoides, and $P$. capitata may have inhibitory activity upon nitric oxide formation in vitro, and this soluble gas is closely related to exudate formation. As expected, the group that was pre-treated with dexamethasone $0.5 \mathrm{mg} / \mathrm{kg}$ also showed reduced exudate formation (\% inhibition: $43.1 \pm 1.6)(\mathrm{p}<0.001)$ (Figure 1c).

Based on these results, we consider $400 \mathrm{mg} / \mathrm{kg}$ to be the optimum dose, as this dose was able to inhibit cell migration and exudate formation triggered by the phlogistic agent in this pleurisy model.

\section{Phytochemical characterization of the alkaloids}

In order to isolate and/or identify the compounds from $P$. stenocalyx crude extract, an acid-base extraction was performed to obtain a purified alkaloid fraction. The HPLC chromatogram at $280 \mathrm{~nm}$ showed the presence of nine major compounds, of which seven were identified (

Fig). The UV spectra displayed by the peaks for these compounds are consistent with $\beta$-carboline (1, 2 and 4), tetrahidro$\beta$-carboline (3) (Passos et al., 2013a) and vallesiachotamine-like nuclei (5-7) (Djerassi et al., 1966).

The alkaloids lyaloside $\mathbf{1}$ and (E)-O-(6')-cinnamoyl-4"hydroxy-3",5"-dimethoxy-lyaloside 2 were identified without isolation by their UV and HRMS data compared to the data available in the literature (Valverde et al., 1999; Passos et al., 2013a). The hyphenated technique HPLC-DAD-SPE was used to isolate the peaks 3-7 of the chromatogram, which was characterized by UV, HRMS, and 1D and 2D NMR spectra compared with data available in the literature.

In the ${ }^{1} \mathrm{H}$ NMR spectra, the specific hydrogen chemical shifts of each isolated compound compared with the literature is coherent with the alkaloids strictosamide 3 (Atta-urRahman et al., 1991), pauridianthoside 4 (Levesque et al., 1977), vallesiachotamine lactone 5 (Passos et al., 2013a), Evallesiachotamine 6, and $Z$-vallesiachotamine 7 (Waterman et al., 1982). The structures of all compounds are shown in

Fig. The compiled data on retention time, mass and UV spectra for all compounds are given in Table 1 .

The ${ }^{1} \mathrm{H}$ NMR spectra of all isolated compounds showed, due to the presence of the benzene ring of the indole system, four aromatic hydrogens: two doublets $\left(\delta_{\mathrm{H} 9}\right.$ and $\left.\delta_{\mathrm{H} 12}\right)$ ortho-coupled with two double-doublets ( $\delta_{\mathrm{H} 10}$ and $\delta_{\mathrm{H} 11}-$ mutually ortho-coupled). All the couplings were confirmed by the 2D COSY spectrum. For the $\beta$-carboline-like alkaloid (4), the ${ }^{1} \mathrm{H}$ NMR spectra showed two doublets $\left(\delta_{\mathrm{H} 5}-\delta_{\mathrm{H} 6}\right)$, while for the tetrahidro- $\beta$-carboline-like $(\mathbf{3})$ and vallesiachotaman-like alkaloid $(\mathbf{5}, \mathbf{6}$, and $\mathbf{7})$ it showed four signals $\left(\delta_{\mathrm{H} 5 \mathrm{a}-\mathrm{b}}-\delta_{\mathrm{H} 6 \mathrm{a}-\mathrm{b}}\right)$ presenting multiplicities coherent with the pattern AA'BB' coupling system. The glycosyl alkaloids $\mathbf{3}$ and $\mathbf{4}$ showed the signal of the anomeric hydrogen as a doublet with coupling constant coherent with a $\beta$-glucose $(J \approx 8 \mathrm{~Hz})$. The HMBC spectrum showed correlations between $\mathrm{C} 21-\mathrm{H} 1$ ' and $\mathrm{C} 1{ }^{\prime}-\mathrm{H} 21$, confirming that the glucoside was linked to the acetal carbon C21.

The isomers $E / Z$-vallesiachotamine, 6 and 7 , were distinguished by the difference between their olefinic H19 signals in the ${ }^{1} \mathrm{H}$ NMR spectra. The $E$-isomer showed a quartet at $\delta_{\mathrm{H} 19}$ $6.79 \mathrm{ppm}$ while for the $Z$-isomer, there was a quartet at $\delta_{\mathrm{H} 19} 6.58$ ppm. The olefinic hydrogen is relatively more deshielded in the $E$ isomer due to the anisotropy of the carbonyl C21 of the aldehyde group. On the other hand, in the $Z$-isomer, the anisotropy of the aldehyde leads to a more deshielded 18-methyl group. Thus, a doublet at $\delta_{\mathrm{H} 18} 2.10 \mathrm{ppm}$ was observed for the $E$-isomer and at $\delta_{\mathrm{H} 18}$ $2.20 \mathrm{ppm}$ for the $Z$-isomer (Waterman et al., 1982). The 1:1 ratio of these $E / Z$ isomers was calculated by the integration of these correspondent peaks in the HPLC chromatogram at $\lambda_{\max } 290 \mathrm{~nm}$. For the vallesiachotamine lactone 5, the NMR data were quite similar to compounds 6 and 7, except for the signals of the $\alpha-\beta$ unsaturated $\gamma$-lactone $\left(\delta_{\mathrm{CH} 18-21}\right)$, linked to the rest of molecule by the carbons $\mathrm{C} 15-\mathrm{C} 20$.

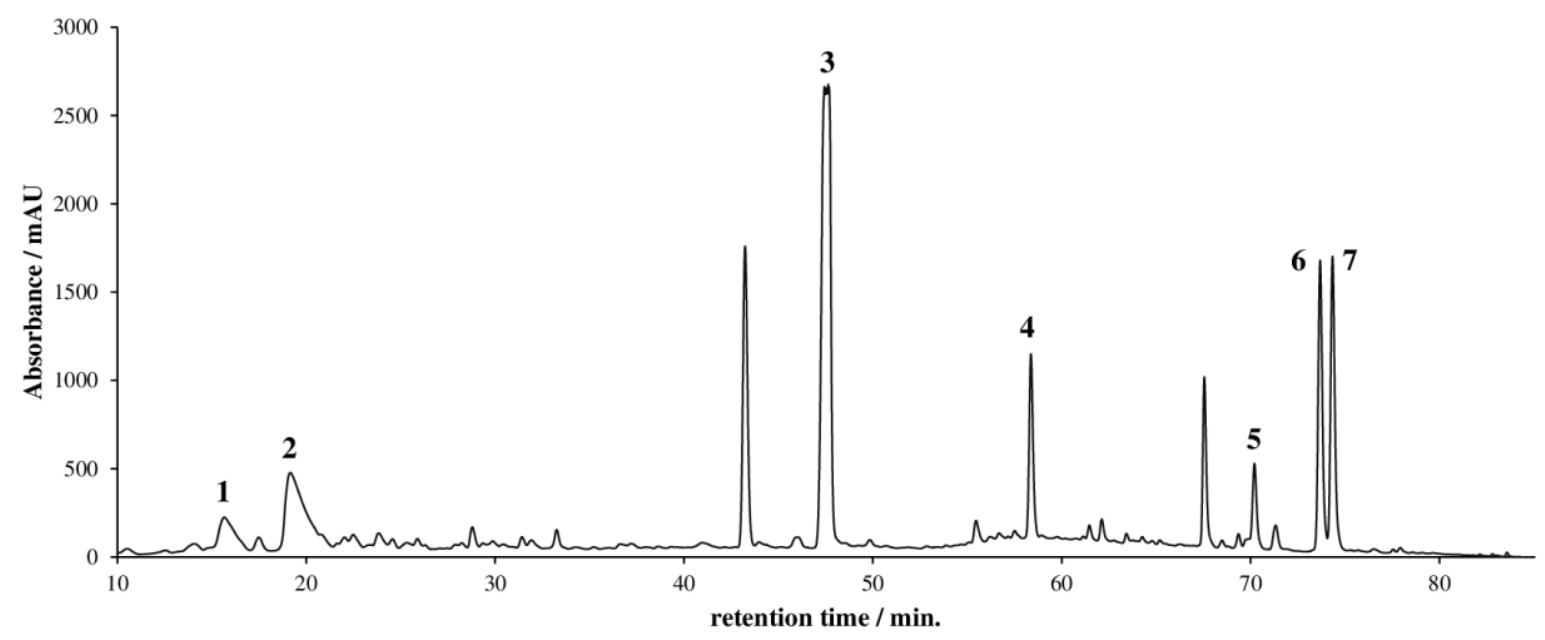

Fig. 2: HPLC chromatogram at $280 \mathrm{~nm}$. The peaks numbered 1-7 (corresponding to compounds 1-7, respectively) were analysed in HPLC-DAD-ESITOF-MS mode [Phenomenex C18 Luna column, $150 \times 4.6 \mathrm{~mm}, 3 \mu \mathrm{m}, 40^{\circ} \mathrm{C}$, elution rate $0.5 \mathrm{~mL} / \mathrm{min}$, elution gradient $0 \mathrm{~min}, 15 \% \mathrm{~B} ; 60 \mathrm{~min}, 65 \% \mathrm{~B}$; $65-75 \mathrm{~min}, 100 \% \mathrm{~B} ; 76-85 \mathrm{~min}, 15 \% \mathrm{~B}$. Injection volume $10 \mu \mathrm{L}$, and $\mathrm{UV}$ traces monitored at 254, 280, and $330 \mathrm{~nm}]$. 
Table 1: Description of the main peaks observed in the HPLC-DAD-ESI-TOF-MS analyses performed for the alkaloid fraction of $P$. stenocalyx leaf extract.

\begin{tabular}{|c|c|c|c|c|c|}
\hline Peak no & $\begin{array}{l}\text { Retention } \\
\text { time (min.) }\end{array}$ & $\begin{array}{c}\text { UV spectrum } \\
\lambda_{\text {max. }}(\mathrm{nm})\end{array}$ & $\begin{array}{c}\text { Molecular } \\
\text { ion }[\mathbf{M}+\mathbf{H}]^{+}\end{array}$ & $\begin{array}{c}\text { Molecular } \\
\text { formula (calc.) }\end{array}$ & compound \\
\hline 1 & 15.9 & $247,303,370$ & 527.2025 & $\mathrm{C}_{27} \mathrm{H}_{31} \mathrm{~N}_{2} \mathrm{O}_{9}{ }^{+}$ & 1 \\
\hline 2 & 19.5 & $239,308,338$ & 733.2582 & $\mathrm{C}_{38} \mathrm{H}_{41} \mathrm{~N}_{2} \mathrm{O}_{13}{ }^{+}$ & 2 \\
\hline 3 & 47.4 & 224,280 & 499.2067 & $\mathrm{C}_{26} \mathrm{H}_{31} \mathrm{~N}_{2} \mathrm{O}_{8}^{+}$ & 3 \\
\hline 5 & 70.3 & 219,290 & 365.1500 & $\mathrm{C}_{21} \mathrm{H}_{21} \mathrm{~N}_{2} \mathrm{O}_{4}^{+}$ & 5 \\
\hline 6 & 73.7 & 225,291 & 351.1709 & $\mathrm{C}_{21} \mathrm{H}_{23} \mathrm{~N}_{2} \mathrm{O}_{3}^{+}$ & 6 \\
\hline 7 & 74.3 & 225,291 & 351.1714 & $\mathrm{C}_{21} \mathrm{H}_{23} \mathrm{~N}_{2} \mathrm{O}_{3}^{+}$ & 7 \\
\hline
\end{tabular}

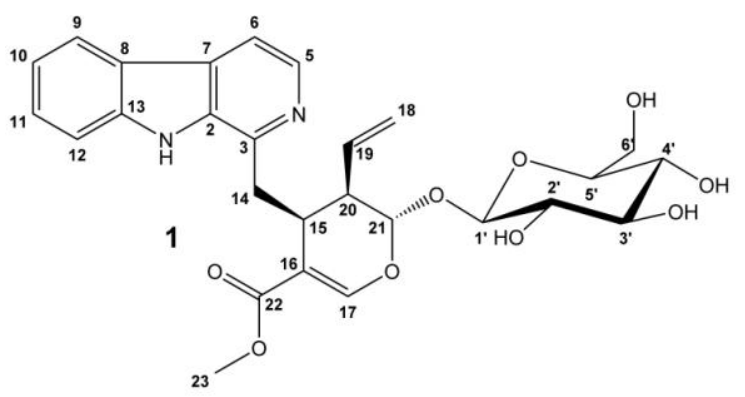

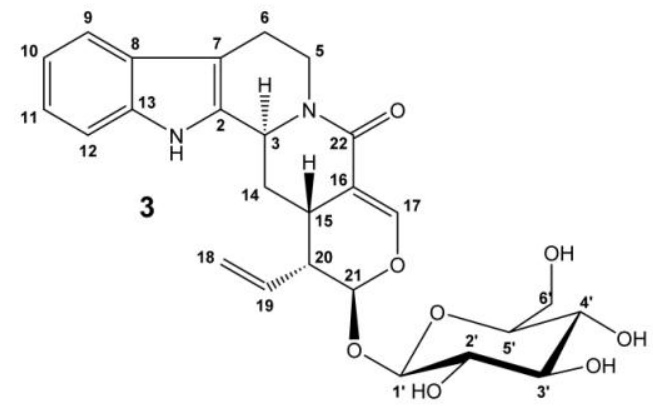
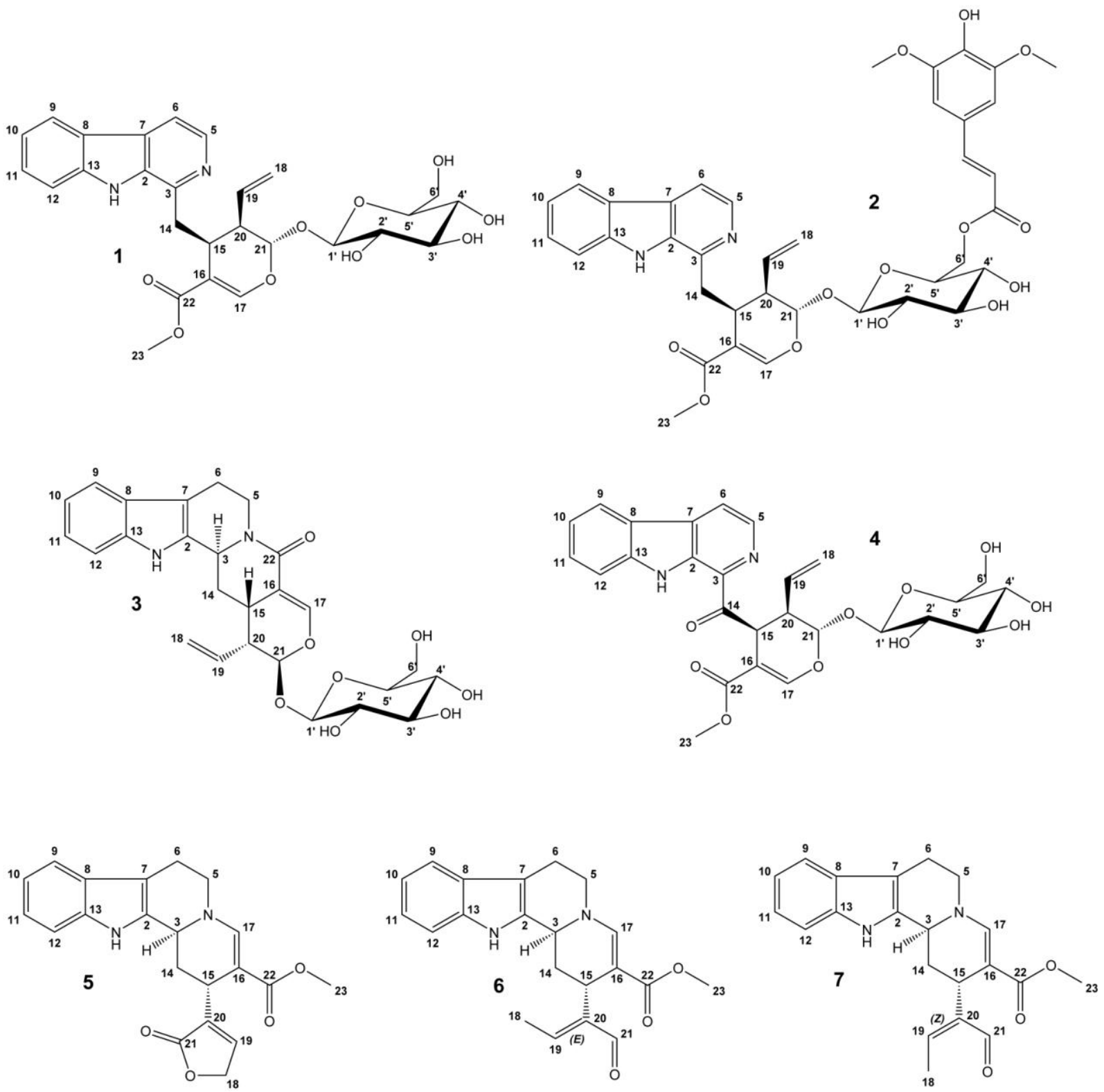

Fig. 3: Monoterpene indole alkaloids (compounds 1-7) identified in the alkaloid fraction of $P$. stenocalyx extract of leaves.

\section{CONCLUSIONS}

$P$. stenocalyx extract of leaves showed preliminary antiinflammatory activity at the $400 \mathrm{mg} / \mathrm{kg}$ dose, by inhibiting leukocyte influx and exudate formation to the pleural cavity after carrageenan administration. From the alkaloid fraction of $P$. stenocalyx extract, the seven known monoterpene indole alkaloids were identified: lyaloside 1, (E)-O-(6')-cinnamoyl-4"-hydroxy3",5"-dimethoxy-lyaloside 2 , strictosamide 3 , pauridianthoside 4 , vallesiachotamine lactone $\mathbf{5}$, E-vallesiachotamine $\mathbf{6}$ and Zvallesiachotamine 7. Although these alkaloids are already known, this is the first biological and phytochemical study with the species P. stenocalyx. 


\section{ACKNOWLEDGEMENTS}

CAPES, CNPq, and FAPESP for financial support. CEBIME/UFSC for the HPLC-HRMS analysis.

Conflict of interests: there are no conflict of interests.

\section{REFERENCES}

Atta-ur-Rahman, Zaman K, Perveen S, Habib-ur-Rehman, Muzaffar A, Choudhary M, Pervin A. Alkaloids from Rhazyastricta. Phytochemistry (Elsevier). 1991; 30(4):1285-1293.

Awad R, Ahmed F, Bourbonnais-Spear N, Mullally M, Ta CA, Tang A, Merali Z, Maquin P, Caal F, Cal V, et al.Ethnopharmacology of Q'eqchi' Maya antiepileptic and anxiolytic plants: Effects on the GABAergic system. J. Ethnopharmacol. 2009; 125(2):257-264.

Berger A, Kostyan MK, Klose SI, Gastegger M, Lorbeer E, Brecker L, Schinnerl J. Loganin and secologanin derived tryptamineiridoid alkaloids from Palicoureacrocea and Palicoureapadifolia (Rubiaceae). Phytochemistry (Elsevier). 2015; 116:162-169.

Bernhard M, Fasshuber H, Robien W, Brecker L, Greger H. Dopamine-iridoid alkaloids in Carapicheaaffinis (=Psychotria borucana) confirm close relationship to the vomiting root Ipecac. Biochem. Syst. Ecol. 2011; 39(3):232-235.

Calixto NO, Pinto MEF, Ramalho SD, Burger MCM, Bobey AF, Young MCM, Bolzani VS, Pinto AC. The Genus Psychotria: Phytochemistry, Chemotaxonomy, Ethnopharmacology and Biological Properties. J. Braz. Chem. Soc. 2016; 27(8):1355-1378.

Currais A, Chiruta C, Goujon-Svrzic M, Costa G, Santos T, Batista MT, Paiva J, Madureira MC, Maher P. Screening and identification of neuroprotective compounds relevant to Alzheimer's disease from medicinal plants of S. Tomé e Príncipe. J. Ethnopharmacol. 2014; 155(1):830-840.

Dillenburg CR, Porto ML, Schultz AR, Instituto de Ciências N. 1985. Rubiaceae: Tribo Psychotrieae, Porto Alegre: Imprensa Universitária.

Djerassi C, Monteiro HJ, Walser A, and Durham LJ. Alkaloid Studies. LVI. The Constitution of Vallesiachotamine. J. Am. Chem. Soc. 1966; 88(8):1792-1798.

Farias FM, Konrath EL, Zuanazzi JAS, Henriques AT. Strictosamide from Psychotria nuda (Cham. etSchltdl) Wawra (Rubiaceae). Biochem. Syst. Ecol. 2008; 36(12):919-920.

Farias FM, Passos CS, Arbo MD, Barros DM, Gottfried C, Steffen VM, Henriques AT. Strictosidinic acid, isolated from Psychotria myriantha Mull. Arg. (Rubiaceae), decreases serotonin levels in rat hippocampus. Fitoterapia. 2012; 83(6):1138-1143.

Flecknell P. Replacement, reduction and refinement. ALTEX. 2002;19(2):73-78

Formagio ASN, Volobuff CRF, Santiago M, Cardoso CAL, Carmo-Vieira M, Pereira ZV. Evaluation of antioxidant activity, total flavonoids, tannins and phenolic compounds in Psychotria leaf extracts. Antioxidants. 2014; 3(4):745-757.

Gerlach SL, Rathinakumar R, Chakravarty G, Goransson U, Wimley WC, Darwin SP, Mondal D. Anticancer and chemosensitizing abilities of cycloviolacin $\mathrm{O} 2$ from Viola odorata and psylecyclotides from Psychotria leptothyrsa. Biopolymers. 2010; 94(5):617-625.

Guerrero EI, Moran-Pinzon JA, Ortiz LG, Olmedo D, Olmo E, Lopez-Perez JL, San FA, Gupta MP. Vasoactive effects of different fractions from two Panamanians plants used in Amerindian traditional medicine. J. Ethnopharmacol. 2010; 131(2):497-501.

Henriques AT, Lopes SO, Paranhos JT, Gregianini TS, Von PGL, Fett-Neto AG, Schripsema J. N, $\beta$ - $D$-Glucopyranosylvincosamide, a light regulated indole alkaloid from the shoots of Psychotria leiocarpa. Phytochemistry (Elsevier). 2004; 65(4):449-454.

Iniyavan M, Sangeetha D, Saravanan S, Parimelazhagan T. Evaluation of antioxidant and pharmacological properties of Psychotria nilgiriensis Deb \& gang. FoodSci. Biotechnol. 2012;21(5):1421-1431.
Kato L, Oliveira CMA, Faria EO, Ribeiro LC, Carvalho BG, da SCC, Schuquel ITA, Santin SMO, Nakamura CV, Britta EA, et al.Antiprotozoal alkaloids from Psychotria prunifolia (Kunth) steyerm. J. Braz. Chem. Soc. 2012; 23(2):355-360.

Levesque J, Pousset JL, and Cave A. Pauridianthoside, a new glucoalkaloid isolated from Pauridianthalyalli. Fitoterapia. 1977; 48(1): 5 7.

Luz ABG, Silva CHB, Nascimento MVPS, de Campos Facchin BM, Baratto B, Fröde TS, Reginatto FH, Dalmarco EM. The antiinflammatory effect of Ilex paraguariensis A. St. Hil (Mate) in a murine model of pleurisy. Int. Immunopharmacol. 2016; 36:165-172.

Moraes TMS, Heggdorne AM, Bernardes NR, Oliveira DB, Lasunskaia EB, Muzitano MF, Cunha Md. Antimycobacterial activity and alkaloid prospection of Psychotria species (Rubiaceae) from the Brazilian Atlantic rainforest. Planta Med. 2011; 77:964-970.

Murillo R and Castro V. Isolation of the alkaloid harmane from Psychotria suerrensis. Ing. Cienc. Quim. 1998; 18(2):61-62.

Nepokroeff M, Bremer B, Sytsma KJ. Reorganization of the genus Psychotria and tribe Psychotrieae (Rubiaceae) inferred from ITS and rbcL sequence data. Systematic Botany. 1999; 24(1):5-27.

Ogino K, Hatanaka K, Kawamura M, Ohno T, Harada Y. Meloxicam Inhibits Prostaglandin E2 Generation via Cyclooxygenase 2 in the Inflammatory Site but Not That via Cyclooxygenase 1 in the Stomach. Pharmacology. 2000; 61(4):244-250.

Passos CS, Simões-Pires CA, Nurisso A, Soldi TC, Kato L, Oliveira CMA, Faria EO, Marcourt L, Gottfried C, Carrupt P-A, et al.Indole alkaloids of Psychotria as multifunctional cholinesterases and monoamine oxidases inhibitors. Phytochemistry (Elsevier). 2013b; 86:820.

Passos CS, Soldi TC, Torres AR, Anders AM, Simões-Pires C, Marcourt L, Gottfried C, Henriques AT. Monoamine oxidase inhibition by monoterpene indole alkaloids and fractions obtained from Psychotria suterella and Psychotria laciniata. J. Enzyme Inhib. Med. Chem. 2013a; 28(3):611-618.

Paul JHA, Maxwell AR, Reynolds WF. Novel Bis(monoterpenoid) Indole Alkaloids from Psychotria bahiensis. J. Nat. Prod. 2003; 66(6):752-754.

Saleh TSF, Calixto JB, Medeiros YS. Anti-inflammatory effects of theophylline, cromolyn and salbutamol in a murine model of pleurisy. Br. J. Pharmacol. 1996; 118(3):811-819.

Schmid-Schönbein GW. Analysis of inflammation. Annu. Rev. Biomed. Eng. 2006; 8:93-151.

Simões-Pires CA, Farias FM, Marston A, Queiroz EF, Chaves CG, Henriques AT, Hostettmann K. Indole monoterpenes with antichemotactic activity from Psychotria myriantha: chemotaxonomic significance. Nat. Prod. Commun. 2006; 1(12):1101-1106.

Taylor, C., Gomes, M., Zappi, D., 2015. Psychotria in Lista de Espécies da Flora do Brasil. Jardim Botânico do Rio de Janeiro [ONLINE].

Availableat: http://floradobrasil.jbri.gov.br/jabot/floradobrasil/FB14219. [Accessed on 20 December 2016].

Valverde J, Tamayo G, and Hesse M. betacarbolinemonoterpenoidglucosidesfromPalicourea adusta. Phytochemistry (Elsevier). 1999; 52(8):1485-1489.

Waterman PG and Zhong S. Vallesiachotamine and isovallesiachotamine from the seeds of Strychnostricalysioides. Planta Med. 1982; 45(1):28-30.

How to cite this article:

Queiroz GS, Luz ABG, Nascimento MVPDS, Thomasi SS, Ferreira AG , Dalmarco EM, Brighente IMC. Phytochemical study and antiinflammatory effect of Psychotria stenocalyx (Rubiaceae). J App Pharm Sci, 2017; 7 (04): 168-173. 